\title{
Intervention with Microfinance for AIDS and Gender Equity (IMAGE): Women's Engagement with the Scaled-up IMAGE Programme and Experience of Intimate Partner Violence in Rural South Africa
}

\author{
L Knight $^{1} \cdot$ M Ranganathan $^{1} \cdot$ T Abramsky $^{1} \cdot$ T Polzer-Ngwato $^{2} \cdot$ L Muvhango $^{3} \cdot$ M Molebatsi $^{2} \cdot$ H Stöckl $^{1} \cdot$ S Lees $^{1} \cdot$ \\ C Watts ${ }^{1}$
}

Published online: 2 December 2019

(C) The Author(s) 2019

\begin{abstract}
The Intervention with Microfinance for AIDS and Gender Equity (IMAGE) programme has been scaled up to three provinces in South Africa. This paper explores associations between women's engagement in the intervention, intimate partner violence (IPV) and factors associated with IPV and partner abuse. We enrolled women receiving group-based microfinance loans plus gender training into the scaled-up IMAGE cohort study $(n=860)$. We present cross-sectional analysis on participants' characteristics and intervention engagement and use multivariate logistic regression to explore associations. $17 \%$ of women reported lifetime $(95 \%$ CI 15 to 20\%) and 7\% past year (95\% CI 5 to 9\%) IPV, 9\% past-year economic (95\% CI 7 to $11 \%$ ) and $11 \%$ past-year emotional (95\% CI 9 to $14 \%$ ) abuse. Women under 35 years had higher levels of IPV and emotional abuse. 53\% of women attended all the trainings, $83 \%$ continuously borrowed and $98 \%$ agreed the training had a major impact on their life. Attendance was associated with improved partner relationships $\left(\chi^{2} p<0.001\right)$, but not lower IPV risk. Odds of past-year IPV decreased the more types of support (e.g. advice) women received from group members (aOR $0.27, p<0.001$ among those reporting all support versus none or some). A similar pattern was seen for economic, but not emotional, abuse. The scaled-up IMAGE intervention is widely acceptable and may support improvements in partner relationships, but younger women need to be targeted. Group support appears to be a potentially important component of the intervention.
\end{abstract}

Keywords Scaled-up intervention · Intimate partner violence prevention · Microfinance plus · Loan groups · Gender training · South Africa

\section{Introduction}

Intimate partner violence (IPV) and human immunodeficiency virus (HIV) are major public health challenges in South Africa; however, evidence on large-scale interventions that have successfully addressed both is sparse

Electronic supplementary material The online version of this article (https://doi.org/10.1007/s11121-019-01070-w) contains supplementary material, which is available to authorized users.

L Knight

Louise.Knight@1shtm.ac.uk

1 London School of Hygiene and Tropical Medicine, 15-17 Tavistock Place, London WC1H 9SH, UK

2 Social Surveys Africa, Johannesburg, South Africa

3 Intervention with Microfinance for AIDS and Gender Equity (IMAGE), Johannesburg, South Africa
(Wagman et al. 2015). According to the 2016 South Africa DHS Survey, 21\% of ever-partnered women aged 18 and older reported lifetime physical IPV, whilst $8 \%$ reported past-year physical IPV; in addition, women reported $6 \%$ and $2 \%$ lifetime and past-year sexual IPV, respectively. HIV prevalence among South African women aged 15-49 years is estimated at approximately $24 \%$ (UNAIDS 2016). In high HIV prevalence settings such as South Africa, HIV infection is highly associated with physical and emotional violence and male controlling behaviour (Durevall and Lindskog 2015).

Poverty, unemployment, lack of economic opportunity and gender inequalities are structural factors that influence both IPV and HIV risk (Gibbs et al. 2017). Microfinance is an approach that increases people's ability to generate income and secure livelihoods (Kennedy et al. 2014). In addition to the economic benefits of microfinance, there is some mixed evidence to suggest that it may be effective as a means for economically empowering women (Gibbs 
et al. 2012; Vyas and Watts 2009; de Mel et al. 2009; Miled and Rejeb 2015; Niner 2019.). The idea is acquiring new business skills may enhance their self-esteem, conflict resolution ability and household decision-making power and expand their social networks (Kim et al. 2009).

The Intervention with Microfinance for AIDS and Gender Equity (IMAGE) programme consists of a group lending microfinance initiative with gender and HIV training (Pronyk et al. 2005a, b). In 2006, a cluster randomised trial conducted in Limpopo region of South Africa showed that the IMAGE intervention was associated with a $55 \%$ reduction in past-year physical and/or sexual IPV (Pronyk et al. 2006), decreased HIV-related risk behaviours in young women (Pronyk et al. 2008) and improved empowerment indicators (Kim et al. 2009). IMAGE is now operational as a violence prevention programme and has been scaled up in three provinces in South Africa with over 25,000 participating households. This transition to an operational programme offered an opportunity to explore whether the IMAGE programme positively influenced women's lives, almost a decade on from when it was first designed in the context of a randomised control trial. In this paper, we aim to describe cohort characteristics and women's engagement with the intervention and explore individual and intervention engagement factors associated with IPV and abuse among rural South African women.

\section{Methods}

\section{Intervention}

IMAGE combines a poverty-focused microfinance initiative implemented by the Small Enterprise Foundation (SEF), with a ten-session participatory curriculum of gender and HIV training known as Sisters for Life (SfL). Loans are administered by SEF for women to develop their own small business. Women attend loan centre meetings and groups of five women guarantee each other's loans. The gender and HIV training is a compulsory component of the routine loan centre meeting and is run by the SfL team generally over a period of 6 months. The SfL intervention is generally delivered over two phases: phase 1 is SfL training that consists of ten 1-h training sessions and covers topics including gender roles, cultural beliefs, relationships, communication, intimate partner violence and HIV, and aims to strengthen communication skills, critical thinking, solidarity and leadership; and phase 2 is community mobilisation that encourages collective action to engage both young people and men in the intervention communities. In this setting, phase 2 differs from the original trial design described in detail elsewhere (Hargreaves et al. 2010) by decentralising the community engagement responsibility from a selection of 'natural leaders' to all women. It consists of training on community engagement and leadership in four sessions over 5 months following phase 1 . This paper describes results from one region, the Mahikeng IMAGE programme, where phase 1 was completed at the time of this survey.

\section{IMAGE Cohort Study Round-One Survey}

The IMAGE cohort study examines changes in loan group women's vulnerability to IPV over two time points, along with other indicators of economic and social empowerment. We calculated our sample size using McNemar's test of paired changes in proportions. This was in order to give us an $80 \%$ power to detect change (at the 5\% significance level) in past-year physical and/or sexual IPV of the same magnitude as seen in the original 2006 IMAGE trial (https://www.statstodo.com/SSizMcNemar Pgm.php). The required sample size was 852 women (further details available on request). We conducted the round-one survey directly after the loan group women had received the phase $1 \mathrm{SfL}$ training and before the completion of phase 2 community engagement. The follow-up survey was conducted a year later. This analysis reports on the round-one cross-sectional survey data only.

\section{Study Setting}

The study took place in rural Mahikeng region in South Africa's North West province. We selected this site as SfL were delivering training in this area in 2016. There are 77 loan centres in the Mahikeng area, comprising a total of 460 loan groups (4-8 loan groups per centre) and a total of 2399 loan recipients (approximately 5 women per group). Due to operational reasons, we included $88 \%$ (68 of 77) of the SEF centres in the Mahikeng region; no crucial differences in population or intervention delivered were anticipated between centres included and those not included. An average of 15 women were survey interviewed per centre (full range 4 to 27 , IQR 11-19).

\section{Survey Procedures}

A South African data collection agency (Social Surveys South Africa (SSA)) co-ordinated and led the fieldwork with London School of Hygiene and Tropical Medicine (LSHTM) researchers providing technical oversight and support. Fifteen female interviewers attended 3 weeks of training on quantitative interviewing techniques and the questionnaire, personal reflections on violence and self-care. All interviewers were trained on violence research ethics, managing disclosures and referral protocols. Interviewer teams were organised into groups of five, including one supervisor. We conducted interviewer-administered survey questionnaires with data captured on to tablet devices. Women were recruited to the study and completed the first-round survey between November and December 2016. All women were offered details of local social and counselling support services at the end of the survey interview. 


\section{Participant Recruitment}

We used the following criteria for selecting participants: women 18 years or older, enrolled for a year or more in the Mahikeng branch of SEF loan centres where SfL training sessions were recently completed. We recruited participants from loan meetings, after introducing the study. The research supervisors selected 10 to 20 women who were attending the meeting on that day by pulling names from an opaque bag and invited selected women to participate in the study. The number of women selected depended on the centre size; 20 in large centres, 15 in small centres, if fewer women were present we invited all to consent. If a woman was unable or unwilling to stay, or refused to consent, the reason was documented. All women were provided with mobile phone airtime worth R50 (4 USD) immediately after the survey interview.

\section{Data Management}

All identifying information was recorded and stored separately from questionnaire responses. Questionnaires were assigned a unique ID. Tablet devices were programmed with logical checks and skips, and data were uploaded directly to a secure server using KoBo Toolkit (www. kobotoolbox.org). Data were managed in excel and Stata14 (StataCorp 2015), and missing or inconsistent data queried with participants, as per the data quality protocol. Data were missing in less than $1 \%$ of cases for the majority of variables used in analysis. Records with missing data were not included in summary statistics or relevant regression models.

\section{Study Measures}

Violence and Abuse Outcome Measures Physical, sexual and emotional IPV questions were adapted from the WHO Multi-country Study on Women's Health and Domestic Violence Against Women survey questions and translated to the local language, Tsetswana. Women who had a partner in the last year were asked about acts of sexual and physical violence and economic abuse experienced in the last 12 months. The definition of a partner included currently married or currently living with a man as if married, partner but not living together, casual boyfriends and any type of partner in the last 12 months (among women not in relationship). Emotional abuse and controlling behaviour questions were adapted from the What Works violence prevention programme (http://www.whatworks. co.za/about/about-what-works) in South Africa. Binary violence outcome variables were constructed with positive responses to one or more violent acts coded as
1 and all others coded as 0 . A full list of violence outcome questions is shown in Table 1 .

IMAGE Intervention Engagement Measures Intervention uptake measures include "Loan borrowing" categorised as continuously borrowed, interrupted or new loan in the last year; "SfL training attendance" categorised as all, half or more and less than half of the training attended. The intervention experience measures include the following: acceptability questions listed in Table. 1 (Hargreaves et al. 2010), with summary measures "Positive about the training and group" and "support provided by the group" shown in Annex 1 in the ESM; and "Microfinance loan influence on relationship" where women were asked how being a member of a microfinance group had influenced their relationship with their partner over the last 12 months, with the following response options: did not affect the relationship, made your relationship more difficult, improved your relationship, not in a relationship. A full description of intervention engagement measures is provided in Annex 1 in the ESM.

Other Constructed Measures We constructed socio-economic status using variables that capture living standards, such as household ownership of durable assets (e.g. TV, fridge) and infrastructure and housing characteristics (e.g. source of water, sanitation facility). We used principle component analysis on asset data to derive a socio-economic status index and then grouped households into categories reflecting different socioeconomic status levels (Vyas and Kumaranayake 2006; Ranganathan et al. 2019)

\section{Analysis}

All analysis presented is exploratory. Sociodemographic characteristics and prevalence of IPV and abuse are described by number and percentage and compared across age groups with associated $\chi^{2} p$ values (Table 2). Crosstabulations between women's characteristics and intervention factors are presented along with $\chi^{2} p$ values (Table 3). To explore associations with lifetime and pastyear IPV and abuse, we fitted a series of logistic regression models. To differentiate risk factors for past-year IPV from those associated with IPV experienced before the last year, we removed those who had experienced IPV prior to the past year only from the denominator (Abramsky et al. 2011; Durevall and Lindskog 2015).

Sociodemographic and sexual behaviour factors shown to be important predictors of IPV and abuse in other settings were selected for bivariate analysis (Abramsky et al. 2011). Multivariate logistic regression models were fitted using factors crudely associated with each outcome at a $p$ value of $<$ 0.05 , as well as age and household assets, which were 
Table 1 Violence questions and indicators of intervention acceptability

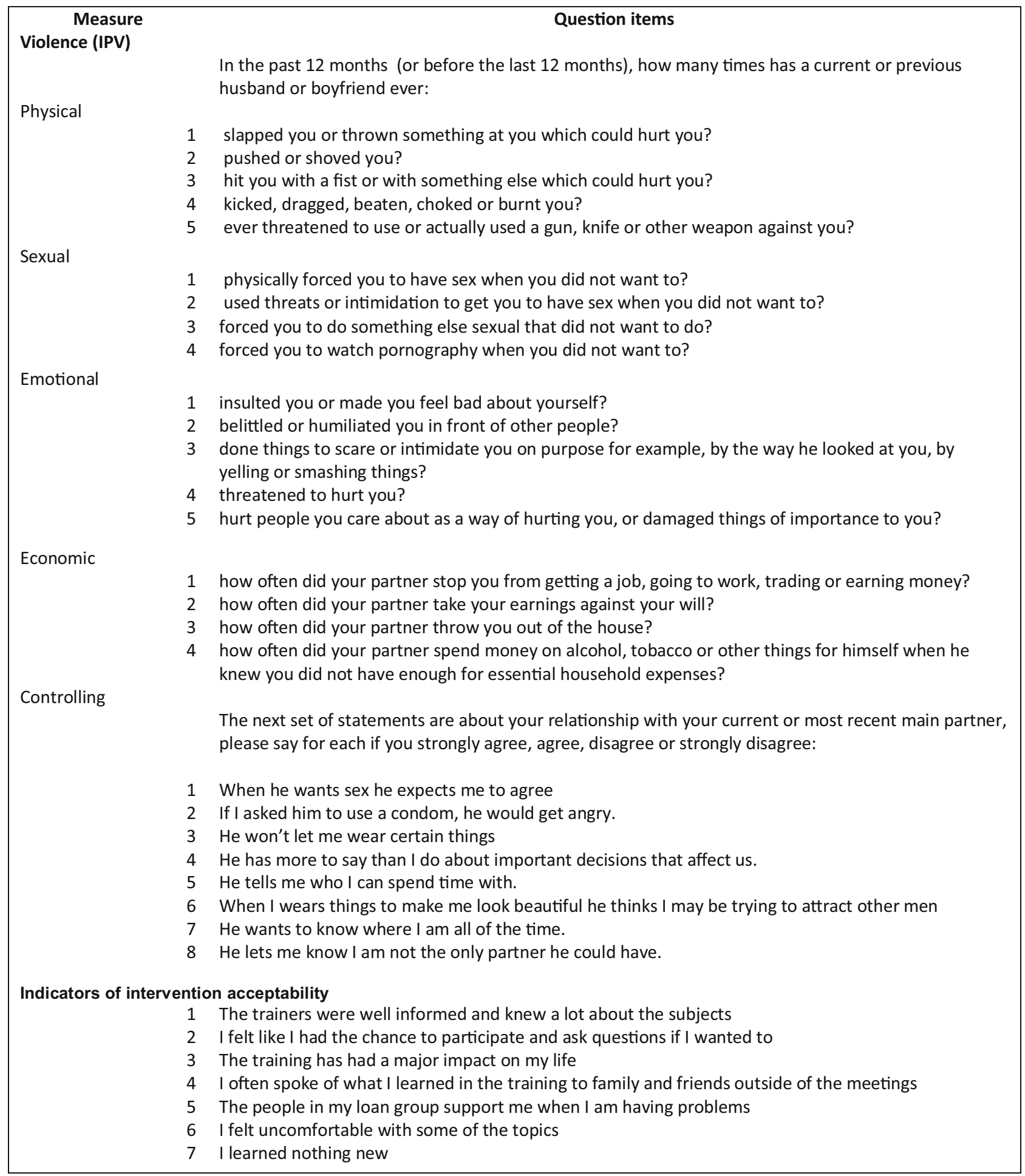

identified a priori (Table 6). Finally, we present associations between intervention engagement and IPV and abuse experienced in the last 12 months. Crude and adjusted odds ratios are shown, with final model adjusted by all intervention engagement factors, age group and household assets selected a priori
(Table 7). In the multivariate regression exploring intervention engagement factors associated with past-year IPV and abuse, we performed sensitivity analyses to explore marriage status, education level and number of children living at home as potential confounding factors. 
Table 2 Sociodemographic characteristics, sexual behaviour and partner violence and abuse, across age groups

\begin{tabular}{|c|c|c|c|c|c|}
\hline & \multirow{2}{*}{$\begin{array}{l}\text { Total sample } \\
n(\%)\end{array}$} & \multicolumn{3}{|l|}{ Age group } & \multirow[b]{2}{*}{$p$ value } \\
\hline & & $\begin{array}{l}21-34 \\
n(\%)\end{array}$ & $\begin{array}{l}35-54 \\
n(\%)\end{array}$ & $\begin{array}{l}55-82 \\
n(\%)\end{array}$ & \\
\hline \multicolumn{6}{|l|}{ Sociodemographic characteristics } \\
\hline Total cohort & 860 & $145(16.9)$ & $409(47.6)$ & $305(35.5)$ & \\
\hline \multicolumn{6}{|l|}{ Marital status } \\
\hline Currently married/living as married & $415(48.2)$ & $61(42.1)$ & $223(54.8)$ & $127(42.3)$ & \multirow[t]{4}{*}{$<0.001$} \\
\hline Divorced/relationship ended & $113(13.2)$ & $7(4.8)$ & $59(14.4)$ & $47(15.4)$ & \\
\hline Widowed & $156(18.2)$ & 0 & $51(12.5)$ & $102(34.4)$ & \\
\hline Never married & $176(20.5)$ & $77(53.1)$ & $75(18.3)$ & $24(7.9)$ & \\
\hline \multicolumn{6}{|l|}{ Level of education ${ }^{a}$} \\
\hline Primary or lower & $334(39.7)$ & $21(14.6)$ & $138(34.8)$ & $175(58.3)$ & \multirow[t]{4}{*}{$<0.001$} \\
\hline Secondary (any grade) & $400(47.6)$ & $89(61.8)$ & $203(51.1)$ & $108(36.0)$ & \\
\hline Passed matric & $87(10.4)$ & $28(19.4)$ & $48(12.1)$ & $11(3.7)$ & \\
\hline Further education & $20(2.4)$ & $6(4.2)$ & $8(2.0)$ & $6(2.0)$ & \\
\hline \multicolumn{6}{|l|}{ Number of children $<18$ living at home } \\
\hline 0 children & $217(25.3)$ & $19(13.1)$ & $69(16.9)$ & $129(42.3)$ & \multirow[t]{3}{*}{$<0.001$} \\
\hline 1-2 children & $363(42.21)$ & $51(35.2)$ & $194(47.4)$ & $118(38.7)$ & \\
\hline $3+$ children & $280(32.6)$ & $75(51.7)$ & $146(35.7)$ & $58(19.0)$ & \\
\hline Female-headed household & $456(53.02)$ & $67(46.2)$ & $205(50.1)$ & $184(60.3)$ & 0.005 \\
\hline \multicolumn{6}{|l|}{ Household assets } \\
\hline Low & $172(20.0)$ & $38(26.2)$ & $89(21.8)$ & $45(14.8)$ & \multirow[t]{3}{*}{0.031} \\
\hline Medium & $512(59.9)$ & $83(57.6)$ & $247(60.5)$ & $182(60.1)$ & \\
\hline High & $172(20.0)$ & $24(16.6)$ & $75(18.3)$ & $73(23.9)$ & \\
\hline \multirow{2}{*}{\multicolumn{6}{|c|}{ Monthly household income ${ }^{\text {a }}$}} \\
\hline & & & & & \\
\hline R2000 or less ( $\$ 142$ USD or less) & $207(24.3)$ & $33(22.9)$ & $98(24.2)$ & $76(25.1)$ & \multirow[t]{5}{*}{0.052} \\
\hline R2001 to R3500 & $231(27.00)$ & $37(25.69)$ & $100(24.69)$ & $93(30.69)$ & \\
\hline R3501 to R5000 & $180(21.13)$ & $27(18.25)$ & $83(20.49)$ & $70(23.10)$ & \\
\hline R5001 to $\mathrm{R} 8000$ & $136(15.96)$ & $23(15.97)$ & $69(17.04)$ & $44(14.52)$ & \\
\hline Over R8000 (over \$571 USD) & $99(11.6)$ & $24(16.7)$ & $55(13.6)$ & $20(6.6)$ & \\
\hline \multicolumn{6}{|l|}{ Sexual behaviour } \\
\hline \multicolumn{6}{|l|}{ Sexual debut ${ }^{a}$} \\
\hline 18 years or older & $608(75.0)$ & $100(69.0)$ & $298(72.9)$ & $254(83.3)$ & \multirow[t]{3}{*}{0.019} \\
\hline 15 to 17 years old & $166(20.4)$ & $36(26.0)$ & $90(22.7)$ & $40(14.4)$ & \\
\hline Under 15 years old & $41(5.0)$ & $9(6.4)$ & $21(5.3)$ & $11(4.0)$ & \\
\hline Condom use at last sex with main partner ${ }^{b}$ & $294(35.6)$ & $69(47.6)$ & $164(41.1)$ & $61(21.6)$ & $<0.001$ \\
\hline $\begin{array}{l}\text { Starting or staying in a relationship in the last } 12 \\
\text { months to receive monetary benefits }\end{array}$ & $55(6.4)$ & $19(13.1)$ & $25(6.1)$ & $11(3.6)$ & 0.001 \\
\hline Two or more sex partners in last 12 months & $78(9.1)$ & $25(17.2)$ & $44(10.8)$ & $9(3.0)$ & $<0.001$ \\
\hline \multicolumn{6}{|l|}{ Partner violence and abuse, lifetime } \\
\hline Physical violence & $128(14.9)$ & $38(26.2)$ & $57(13.9)$ & $33(10.8)$ & $<0.001$ \\
\hline Sexual violence & $65(7.6)$ & $9(6.2)$ & $38(9.3)$ & $18(5.9)$ & 0.189 \\
\hline Physical and/or sexual violence & $146(17.0)$ & $41(28.3)$ & $71(17.4)$ & $34(11.2)$ & $<0.001$ \\
\hline Economic abuse & $123(14.3)$ & $29(20.0)$ & $59(14.4)$ & $35(11.5)$ & 0.054 \\
\hline \multicolumn{6}{|l|}{ Partner violence and abuse, last 12 months } \\
\hline Physical violence & $46(5.4)$ & $25(17.2)$ & $16(3.9)$ & $5(1.6)$ & $<0.001$ \\
\hline Sexual violence & $25(2.9)$ & $7(4.8)$ & $10(2.4)$ & $8(2.6)$ & 0.318 \\
\hline Physical and/or sexual violence & $57(6.6)$ & $27(18.6)$ & $20(4.9)$ & $10(3.3)$ & $<0.001$ \\
\hline Economic abuse & $77(9.0)$ & $21(14.5)$ & $38(9.3)$ & $18(5.9)$ & 0.011 \\
\hline Emotional abuse & $96(11.2)$ & $33(22.8)$ & $45(11.0)$ & $18(5.9)$ & $<0.001$ \\
\hline $\begin{array}{l}\text { Partner controlling behaviour, in current or } \\
\text { most recent relationship }\end{array}$ & $448(52.1)$ & $98(67.6)$ & $234(57.2)$ & $115(37.7)$ & $<0.001$ \\
\hline Partner violence, abuse or control, life time & $500(58.2)$ & $110(75.9)$ & $257(62.8)$ & $133(43.6)$ & $<0.001$ \\
\hline
\end{tabular}

Missing data: ${ }^{\text {a }} 1$ age, $5(1 \%)$ household SES, 8 (1\%) household income, $9(1 \%)$ number in household, 19 (2\%) education, $44(5 \%)$ sexual debut; ${ }^{\text {b }} n=$ 826 as 18 refused to answer and 15 said they had not had sex since the first time 


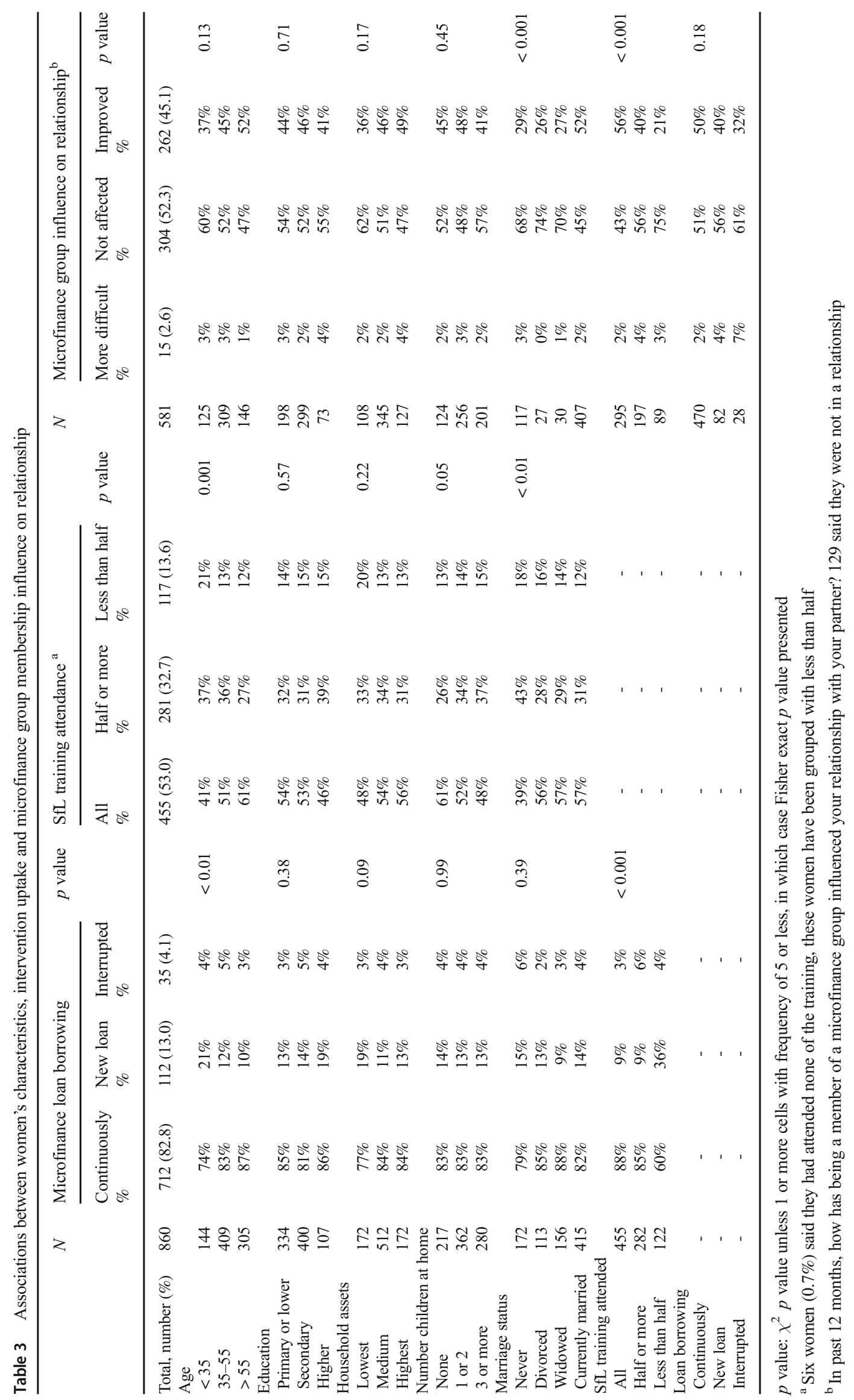




\section{Results}

\section{Participants}

A total of 937 eligible women attending loan groups were selected and invited to consent to the study, of whom 860 (92\%) consented and completed a cross-sectional survey. Reasons for not consenting included the following: health reasons, going to post office to make loan payment, going to work, school or funeral, and no time.

\section{Participant Characteristics and Comparisons Across Age Groups}

The median age of the women was 48 years, with over a third aged over 55 years. Almost half were currently married or living as if married, $40 \%$ did not reach secondary school education and a quarter reported a monthly household income of less than $\$ 142$ USD. Younger women, defined as under 35 years old throughout this manuscript, lived in households with fewer assets and had more children living at home. HIV risk behaviours varied across age groups; older women reported less condom use, whilst younger women reported earlier sexual debut, more partners in the last 12 months and a greater likelihood of having started or stayed in a relationship in the last year to receive monetary benefits.

\section{Prevalence of Partner Violence and Abuse}

Lifetime and past-year prevalence of partner physical and/or sexual violence for the entire cohort was $17 \%$ (95\% CI 15 to $20 \%$ ) and $7 \%$ (95\% CI 5 to 9\%), respectively (Table 2). The past-year prevalence of economic and emotional partner abuse was $9 \%$ (95\% CI 7 to $11 \%$ ) and $11 \%$ (95\% CI 9 to 14\%), respectively. Controlling behaviour in current/most recent relationship was reported by 53\% (95\% CI 49-56\%) of women.

\section{Intervention Uptake and Influence on Relationship}

Table 3 presents cross-tabulations of women's sociodemographic characteristics and self-reports of loan borrowing, SfL training attendance and influence of the microfinance loans on relationships. Most women borrowed continuously over the last year; however, $13 \%$ started a new loan, and $4 \%$ had interrupted borrowing. The most common reason given for interrupted borrowing was the inability to personally pay back loans or due to group payment issues; other reasons were personal issues such as sickness or travel and business issues such as "not selling". Over half attended all of the training sessions, a third attended more than half but not all and the remaining $14 \%$ attended less than half, including six women who attended none. Of the women who said they were in a current relationship, $3 \%$ said that being a member of a microfinance group made their relationship more difficult, 52\% said it had not affected their relationship and $45 \%$ said it had improved their relationship.

Younger women, those who attended less SfL training and those in the lowest socio-economic status households, were more likely to report having started a new loan in the past year. Younger women, those currently unmarried nor living as married and those who had children living with them, reported attending less SfL training. Greater training attendance was associated with women who were more likely to report improved relationships with their partner, with women attending all the sessions being the most likely to report an improvement and the least likely to report that relationship had become more difficult. Younger women, those with fewer household assets and those who interrupted loan borrowing, were less likely to report an improvement in their relationship; however, these associations did not reach statistical significance.

\section{Intervention Acceptability and Group Support}

Table 4 shows that the majority of women were positive about the intervention. Most women reported that members of their group provided the various types of support pertaining to financial, business, personal and emotional concerns; however, material support such as clothes and food was reported to a much lesser extent.

Table 5 shows intervention summary measures. Just under half the women were highly positive about all aspects of the training and over half of the women reported that all types of support were provided by the group members. Notably, there was no difference between age groups with regard to a positive attitude about the training, engagement with the topics or support provided from the group (Annex 1 in the ESM).

\section{Individual Factors Associated with Intimate Partner Violence and Abuse}

Table 6 presents associations between women's sociodemographic factors and both lifetime and past-year experiences of IPV and abuse. Women aged over 55 had lower odds, and women who had earned money in the last year had higher odds, of lifetime sexual and/or physical IPV. Women reporting earlier sexual debut had higher odds of lifetime and double the odds of past-year sexual and/or physical IPV, compared with women whose sexual debut occurred at 18+ years of age. Younger women had a much greater risk of recent IPV and recent emotional abuse with older age groups having approximately a third the odds of sexual and/or physical IPV and emotional abuse in the last year. Women who reported two or more sexual partners in the past year had almost three times the odds of recent emotional abuse compared to those with fewer partners. 
Table 4 Indicators of intervention acceptability

\begin{tabular}{|c|c|c|c|c|}
\hline Indicators of acceptability & $\begin{array}{l}\text { I strongly agree } \\
n(\%)\end{array}$ & $\begin{array}{l}\text { I agree } \\
n(\%)\end{array}$ & $\begin{array}{l}\text { I disagree } \\
n(\%)\end{array}$ & $\begin{array}{l}\text { I strongly disagree } \\
n(\%)\end{array}$ \\
\hline \multicolumn{5}{|l|}{ Positive about training and group: } \\
\hline 1. The trainers were well informed and knew a lot about the subjects & $731(85.6)$ & $114(13.4)$ & $5(0.6)$ & $4(0.5)$ \\
\hline $\begin{array}{l}\text { 2. I felt like I had the chance to participate and } \\
\text { ask questions if I wanted to }\end{array}$ & $583(68.3)$ & $236(27.6)$ & $23(2.7)$ & $12(1.4)$ \\
\hline 3. The training has had a major impact on my life & $641(75.1)$ & $202(23.7)$ & $5(0.6)$ & $6(0.7)$ \\
\hline $\begin{array}{l}\text { 4. I often spoke of what I learned in the training to } \\
\text { family and friends outside of the meetings }\end{array}$ & $637(74.6)$ & $180(21.1)$ & $21(2.5)$ & $16(1.9)$ \\
\hline $\begin{array}{l}\text { 5. The people in my loan group support me } \\
\text { when I am having problems }\end{array}$ & $606(71.0)$ & $203(23.8)$ & $33(3.9)$ & $12(1.4)$ \\
\hline \multicolumn{5}{|l|}{ Views on the training: } \\
\hline 6. I felt uncomfortable with some of the topics & $204(23.9)$ & $115(13.5)$ & $221(25.9)$ & $314(36.8)$ \\
\hline 7. I learned nothing new & $192(22.8)$ & $27(3.1)$ & $130(15.2)$ & $502(58.8)$ \\
\hline
\end{tabular}

Earlier sexual debut was consistently associated with partner economic abuse, whilst, women's current age was not associated with economic abuse, in the adjusted models. Living in a house with more assets seems to be protective, with women in households with medium or high number of assets having half the odds of abuse compared with those with the least number of assets. Women who attended secondary school had double the odds of economic abuse compared with those with less education attainment and having children living at home is associated with more than double the odds of experiencing past-year economic abuse.

\section{Intervention Engagement Association with Intimate Partner Violence and Abuse}

Table 7 presents logistic regression crude and adjusted odds ratios showing associations between intervention factors and past-year IPV and abuse. Compared with continuous borrowing, interrupted loan borrowing over the last year was associated with three times higher odds of pastyear emotional abuse (aOR 3.02, $p=0.01$ ), whereas starting a new loan in the last year was associated with higher odds of past-year economic abuse (aOR 2.62, $p \leq$ 0.001 ). Attending half or more, but not all, of the training sessions was associated with reporting less emotional abuse in the last year compared with those women

Table 5 Types of support provided by group members

\begin{tabular}{ll}
\hline Types of support provided by group members & Yes, $n(\%), n=860$ \\
\hline Help with financial issues & $774(90.0)$ \\
Advice with business issues & $781(90.8)$ \\
Advice with personal issues & $744(86.5)$ \\
Other material support (such as food or clothing) & $471(54.8)$ \\
Emotional support (love, caring, friendship) & $763(88.7)$ \\
\hline
\end{tabular}

attending all the sessions (aOR 0.52, $p=0.02$ ). Women reporting all types of support provided from the group, compared with none or some support, had almost a quarter the odds of past-year physical and/or sexual violence (aOR $0.27, p \leq 0.001)$. Similarly, most types of support provided (aOR $0.38, p=0.01$ ) and all types of support provided (aOR $0.41, p=0.01$ ) from the group members was associated with reduced odds of women reporting past-year economic abuse. The sensitivity analysis, which included additionally adjusting for marriage status, number of children living at home and education attainment, produced similar results.

\section{Discussion}

\section{Intervention Delivery and Acceptability at Scale}

The Mahikeng IMAGE operational programme retained the same original trial intervention components of SEF group loans and phase $1 \mathrm{SfL}$ training topics; however, the phase 2 community mobilisation component had not been delivered at the time of round-one survey. In our cohort, $24 \%$ of women reported a monthly household an income of $<\$ 142 / \mathrm{R} 2000$, and $72 \%$ reported less than the North West province average (based on exchanged rates in 2016 and the South African Census 2011). This indicates that, as intended, the operational intervention is reaching the poorest women in the province. Among our sample of women attending loan group meetings, most had continuously borrowed over the last year (83\%) and attended half or more of the SfL training (86\%). Women's responses to the operational intervention acceptability questions were similar, or higher, than reported by those women participants in the original trial and immediate scale-up (Hargreaves et al. 2010). 
Table 6 Factors associated with lifetime and recent partner violence and abuse

\begin{tabular}{|c|c|c|c|c|c|c|c|c|c|c|}
\hline & \multicolumn{2}{|c|}{$\begin{array}{l}\text { Partner physical and/ } \\
\text { or sexual violence }\end{array}$} & \multicolumn{2}{|c|}{$\begin{array}{l}\text { Partner physical and/ } \\
\text { or sexual violence }\end{array}$} & \multicolumn{2}{|c|}{$\begin{array}{l}\text { Partner emotional } \\
\text { abuse }\end{array}$} & \multicolumn{2}{|c|}{$\begin{array}{l}\text { Partner economic } \\
\text { abuse }\end{array}$} & \multicolumn{2}{|c|}{$\begin{array}{l}\text { Partner economic } \\
\text { abuse }\end{array}$} \\
\hline & \multicolumn{2}{|l|}{ Lifetime } & \multicolumn{2}{|c|}{ Last 12 months $^{\mathrm{a}}$} & \multicolumn{2}{|c|}{ Last 12 months } & \multicolumn{2}{|l|}{ Lifetime $^{\mathrm{b}}$} & \multicolumn{2}{|c|}{ Last 12 months ${ }^{\mathrm{a}, \mathrm{b}}$} \\
\hline & $\begin{array}{l}\text { OR } \\
95 \% \mathrm{CI} \\
p \text { value }\end{array}$ & $\begin{array}{l}\mathrm{aOR} \\
95 \% \mathrm{CI} \\
p \text { value }\end{array}$ & $\begin{array}{l}\text { OR } \\
95 \% \mathrm{CI} \\
p \text { value }\end{array}$ & $\begin{array}{l}\mathrm{aOR} \\
95 \% \mathrm{CI} \\
p \text { value }\end{array}$ & $\begin{array}{l}\text { OR } \\
95 \% \mathrm{CI} \\
p \text { value }\end{array}$ & $\begin{array}{l}\mathrm{aOR} \\
95 \% \mathrm{CI} \\
p \text { value }\end{array}$ & $\begin{array}{l}\text { OR } \\
95 \% \mathrm{CI} \\
p \text { value }\end{array}$ & $\begin{array}{l}\text { aOR } \\
95 \% \mathrm{CI} \\
p \text { value }\end{array}$ & $\begin{array}{l}\text { OR } \\
95 \% \mathrm{CI} \\
p \text { value }\end{array}$ & $\begin{array}{l}\mathrm{aOR} \\
95 \% \mathrm{CI} \\
p \text { value }\end{array}$ \\
\hline Total number in model & 859 & 848 & 771 & 749 & 860 & 837 & 859 & 848 & 814 & 791 \\
\hline \multicolumn{11}{|l|}{ Age group } \\
\hline$<35$ years & ref & ref & ref & ref & ref & ref & ref & ref & ref & ref \\
\hline $35-55$ year & $\begin{array}{l}0.53 \\
0.34-0.83 \\
0.01\end{array}$ & $\begin{array}{l}0.53 \\
0.36-0.96 \\
0.03\end{array}$ & $\begin{array}{l}0.23 \\
0.12-0.42 \\
<0.001\end{array}$ & $\begin{array}{l}0.35 \\
0.18-0.68 \\
0.002\end{array}$ & $\begin{array}{l}0.42 \\
0.26-0.69 \\
0.001\end{array}$ & $\begin{array}{l}0.52 \\
0.30-0.90 \\
0.02\end{array}$ & $\begin{array}{l}0.67 \\
0.41-1.10 \\
0.12\end{array}$ & $\begin{array}{l}0.79 \\
0.46-1.36 \\
0.40\end{array}$ & $\begin{array}{l}0.60 \\
0.34-1.06 \\
0.08\end{array}$ & $\begin{array}{l}0.87 \\
0.46-1.65 \\
0.67\end{array}$ \\
\hline $55+$ years & $\begin{array}{l}0.32 \\
0.19-0.53 \\
<0.001\end{array}$ & $\begin{array}{l}0.42 \\
0.23-0.77 \\
0.01\end{array}$ & $\begin{array}{l}0.14 \\
0.07-0.30 \\
<0.001\end{array}$ & $\begin{array}{l}0.34 \\
0.14-0.88 \\
0.03\end{array}$ & $\begin{array}{l}0.21 \\
0.12-0.39 \\
<0.001\end{array}$ & $\begin{array}{l}0.38 \\
0.97-2.87 \\
0.06\end{array}$ & $\begin{array}{l}0.52 \\
0.30-0.89 \\
0.02\end{array}$ & $\begin{array}{l}0.82 \\
0.43-1.55 \\
0.54\end{array}$ & $\begin{array}{l}0.37 \\
0.19-0.72 \\
0.01\end{array}$ & $\begin{array}{l}1.00 \\
0.43-2.30 \\
0.57\end{array}$ \\
\hline \multicolumn{11}{|l|}{ Household assets } \\
\hline Low & ref & ref & ref & ref & ref & ref & ref & ref & ref & ref \\
\hline Medium & $\begin{array}{l}0.84 \\
0.57-1.27 \\
0.42\end{array}$ & $\begin{array}{l}0.80 \\
0.50-1.29 \\
0.37\end{array}$ & $\begin{array}{l}0.84 \\
0.44-1.59 \\
0.59\end{array}$ & $\begin{array}{l}0.75 \\
0.37-1.51 \\
0.42\end{array}$ & $\begin{array}{l}1.10 \\
0.63-1.88 \\
0.77\end{array}$ & $\begin{array}{l}0.96 \\
0.53-1.73 \\
0.89\end{array}$ & $\begin{array}{l}0.82 \\
0.51-1.31 \\
0.40\end{array}$ & $\begin{array}{l}0.71 \\
0.43-1.16 \\
0.17\end{array}$ & $\begin{array}{l}0.65 \\
0.37-1.13 \\
0.13\end{array}$ & $\begin{array}{l}0.52 \\
0.28-0.97 \\
0.04\end{array}$ \\
\hline High & $\begin{array}{l}1.00 \\
0.59-1.73 \\
0.80\end{array}$ & $\begin{array}{l}1.12 \\
0.62-1.99 \\
0.71\end{array}$ & $\begin{array}{l}0.50 \\
0.20-1.29 \\
0.15\end{array}$ & $\begin{array}{l}0.47 \\
0.17-1.31 \\
0.15\end{array}$ & $\begin{array}{l}0.83 \\
0.41-1.68 \\
0.61\end{array}$ & $\begin{array}{l}0.73 \\
0.34-1.58 \\
0.43\end{array}$ & $\begin{array}{l}0.71 \\
0.38-1.27 \\
0.23\end{array}$ & $\begin{array}{l}0.56 \\
0.29-1.06 \\
0.08\end{array}$ & $\begin{array}{l}0.64 \\
0.31-1.30 \\
0.21\end{array}$ & $\begin{array}{l}0.51 \\
0.23-1.13 \\
0.10\end{array}$ \\
\hline \multicolumn{11}{|l|}{ Marriage status } \\
\hline Never married & ref & ref & ref & ref & ref & ref & ref & ref & ref & ref \\
\hline Divorced/separated & $\begin{array}{l}0.60 \\
0.33-1.11 \\
0.11\end{array}$ & $\begin{array}{l}0.75 \\
0.38-1.45 \\
0.38\end{array}$ & $\begin{array}{l}0.13 \\
0.03-0.59 \\
0.01\end{array}$ & $\begin{array}{l}0.24 \\
0.05-1.12 \\
0.07\end{array}$ & $\begin{array}{l}0.58 \\
0.26-1.29 \\
0.18\end{array}$ & $\begin{array}{l}1.06 \\
0.44-2.57 \\
0.89\end{array}$ & $\begin{array}{l}0.52 \\
0.30-0.92 \\
0.02\end{array}$ & $\begin{array}{l}0.67 \\
0.36-1.28 \\
0.23\end{array}$ & $\begin{array}{l}0.09 \\
0.03-0.33 \\
<0.001\end{array}$ & $\begin{array}{l}0.16 \\
0.04-0.60 \\
0.01\end{array}$ \\
\hline Widowed & $\begin{array}{l}0.31 \\
0.16-0.60 \\
<0.001\end{array}$ & $\begin{array}{l}0.47 \\
0.23-0.98 \\
0.04\end{array}$ & $\begin{array}{l}0.04 \\
0.01-0.34 \\
<0.001\end{array}$ & $\begin{array}{l}0.13 \\
0.02-1.04 \\
0.05\end{array}$ & $\begin{array}{l}0.09 \\
0.02-0.37 \\
<0.001\end{array}$ & $\begin{array}{l}0.23 \\
0.05-1.08 \\
0.06\end{array}$ & - & - & - & - \\
\hline Married/living as if married & $\begin{array}{l}0.67 \\
0.44-1.03 \\
0.07\end{array}$ & $\begin{array}{l}0.76 \\
0.47-1.22 \\
0.26\end{array}$ & $\begin{array}{l}0.61 \\
0.34-1.10 \\
0.10\end{array}$ & $\begin{array}{l}0.72 \\
0.32-1.60 \\
0.18\end{array}$ & $\begin{array}{l}1.17 \\
0.70-1.95 \\
0.55\end{array}$ & $\begin{array}{l}1.21 \\
0.61-2.42 \\
0.59\end{array}$ & $\begin{array}{l}0.94 \\
0.58-1.50 \\
0.79\end{array}$ & $\begin{array}{l}0.83 \\
0.44-1.58 \\
0.58\end{array}$ & $\begin{array}{l}1.21 \\
0.70-2.12 \\
0.50\end{array}$ & $\begin{array}{l}1.35 \\
0.64-2.86 \\
0.43\end{array}$ \\
\hline \multicolumn{11}{|l|}{ Level of education } \\
\hline Primary or lower & ref & ref & ref & ref & ref & ref & ref & - & ref & ref \\
\hline Secondary (any grade) & $\begin{array}{l}1.51 \\
1.02-2.24 \\
0.04\end{array}$ & $\begin{array}{l}1.17 \\
0.76-1.79 \\
0.49\end{array}$ & $\begin{array}{l}2.21 \\
1.14-4.29 \\
0.02\end{array}$ & $\begin{array}{l}1.60 \\
0.77-3.33 \\
0.21\end{array}$ & $\begin{array}{l}2.07 \\
1.25-3.42 \\
0.01\end{array}$ & $\begin{array}{l}1.66 \\
0.97-2.86 \\
0.07\end{array}$ & $\begin{array}{l}1.48 \\
0.98-2.14 \\
0.07\end{array}$ & - & $\begin{array}{l}2.09 \\
1.21-3.60 \\
0.01\end{array}$ & $\begin{array}{l}2.0 \\
1.11-3.70 \\
0.02\end{array}$ \\
\hline Pass metric & $\begin{array}{l}1.38 \\
0.74-2.58 \\
0.31\end{array}$ & $\begin{array}{l}0.93 \\
0.76-1.79 \\
0.82\end{array}$ & $\begin{array}{l}3.12 \\
1.31-7.41 \\
0.01\end{array}$ & $\begin{array}{l}1.93 \\
0.74-5.04 \\
0.18\end{array}$ & $\begin{array}{l}2.07 \\
0.99-4.33 \\
0.05\end{array}$ & $\begin{array}{l}1.58 \\
0.71-3.51 \\
0.92\end{array}$ & $\begin{array}{l}0.80 \\
0.38-1.72 \\
0.58\end{array}$ & - & $\begin{array}{l}1.50 \\
0.64-3.54 \\
0.35\end{array}$ & $\begin{array}{l}1.33 \\
0.52-3.40 \\
0.55\end{array}$ \\
\hline Further education & $\begin{array}{l}0.68 \\
0.15-3.03 \\
0.61\end{array}$ & $\begin{array}{l}0.40 \\
0.08-1.91 \\
0.25\end{array}$ & $\begin{array}{l}1.23 \\
0.15-9.94 \\
0.85\end{array}$ & $\begin{array}{l}0.92 \\
0.09-9.21 \\
0.94\end{array}$ & $\begin{array}{l}1.44 \\
0.32-6.57 \\
0.64\end{array}$ & $\begin{array}{l}0.92 \\
0.18-4.77 \\
0.92\end{array}$ & $\begin{array}{l}0.37 \\
0.05-2.81 \\
0.34\end{array}$ & - & $\begin{array}{l}0.77 \\
0.10-6.06 \\
0.81\end{array}$ & $\begin{array}{l}1.08 \\
0.12-9.88 \\
0.95\end{array}$ \\
\hline $\begin{array}{l}\text { Two or more sexual partners in } \\
12 \text { months }\end{array}$ & $\begin{array}{l}1.41 \\
0.80-2.50 \\
0.24\end{array}$ & - & $\begin{array}{l}2.28 \\
1.10-4.73 \\
0.03\end{array}$ & $\begin{array}{l}1.48 \\
0.67-3.31 \\
0.12\end{array}$ & $\begin{array}{l}3.47 \\
2.00-6.04 \\
<0.001\end{array}$ & $\begin{array}{l}2.74 \\
1.52-4.95 \\
<0.001\end{array}$ & $\begin{array}{l}1.35 \\
0.73-2.49 \\
0.34\end{array}$ & - & $\begin{array}{l}2.14 \\
1.12-4.09 \\
0.02\end{array}$ & $\begin{array}{l}1.69 \\
0.83-3.43 \\
0.15\end{array}$ \\
\hline \multicolumn{11}{|l|}{ Sexual debut } \\
\hline 18 years and over & ref & ref & ref & ref & ref & - & ref & ref & ref & ref \\
\hline 15 to 17 years old & $\begin{array}{l}1.82 \\
1.20-2.76 \\
0.01\end{array}$ & $\begin{array}{l}1.77 \\
1.14-2.73 \\
0.01\end{array}$ & $\begin{array}{l}2.14 \\
1.16-3.95 \\
0.01\end{array}$ & $\begin{array}{l}2.10 \\
1.10-4.10 \\
0.03\end{array}$ & $\begin{array}{l}1.43 \\
0.86-2.38 \\
0.17\end{array}$ & - & $\begin{array}{l}1.91 \\
1.23-3.00 \\
<0.001\end{array}$ & $\begin{array}{l}1.80 \\
1.17-2.94 \\
0.01\end{array}$ & $\begin{array}{l}1.84 \\
1.14-2.83 \\
0.01\end{array}$ & $\begin{array}{l}1.95 \\
1.09-3.49 \\
0.03\end{array}$ \\
\hline
\end{tabular}


Table 6 (continued)

\begin{tabular}{|c|c|c|c|c|c|c|c|c|c|c|}
\hline & \multicolumn{2}{|c|}{$\begin{array}{l}\text { Partner physical and/ } \\
\text { or sexual violence }\end{array}$} & \multicolumn{2}{|c|}{$\begin{array}{l}\text { Partner physical and/ } \\
\text { or sexual violence }\end{array}$} & \multicolumn{2}{|c|}{$\begin{array}{l}\text { Partner emotional } \\
\text { abuse }\end{array}$} & \multicolumn{2}{|c|}{$\begin{array}{l}\text { Partner economic } \\
\text { abuse }\end{array}$} & \multicolumn{2}{|c|}{$\begin{array}{l}\text { Partner economic } \\
\text { abuse }\end{array}$} \\
\hline & \multicolumn{2}{|l|}{ Lifetime } & \multicolumn{2}{|c|}{ Last 12 months $^{\mathrm{a}}$} & \multicolumn{2}{|c|}{ Last 12 months } & \multicolumn{2}{|l|}{ Lifetime $^{\mathrm{b}}$} & \multicolumn{2}{|c|}{ Last 12 months $^{\mathrm{a}, \mathrm{b}}$} \\
\hline & $\begin{array}{l}\mathrm{OR} \\
95 \% \mathrm{CI} \\
p \text { value }\end{array}$ & $\begin{array}{l}\text { aOR } \\
95 \% \mathrm{CI} \\
p \text { value }\end{array}$ & $\begin{array}{l}\text { OR } \\
95 \% \mathrm{CI} \\
p \text { value }\end{array}$ & $\begin{array}{l}\mathrm{aOR} \\
95 \% \mathrm{CI} \\
p \text { value }\end{array}$ & $\begin{array}{l}\text { OR } \\
95 \% \mathrm{CI} \\
p \text { value }\end{array}$ & $\begin{array}{l}\mathrm{aOR} \\
95 \% \mathrm{CI} \\
p \text { value }\end{array}$ & $\begin{array}{l}\text { OR } \\
95 \% \mathrm{CI} \\
p \text { value }\end{array}$ & $\begin{array}{l}\mathrm{aOR} \\
95 \% \mathrm{CI} \\
p \text { value }\end{array}$ & $\begin{array}{l}\text { OR } \\
95 \% \mathrm{CI} \\
p \text { value }\end{array}$ & $\begin{array}{l}\text { aOR } \\
95 \% \mathrm{CI} \\
p \text { value }\end{array}$ \\
\hline Under 15 years old & $\begin{array}{l}1.61 \\
0.75-3.50 \\
0.22\end{array}$ & $\begin{array}{l}1.69 \\
1.14-2.73 \\
0.20\end{array}$ & $\begin{array}{l}2.48 \\
0.91-6.76 \\
0.08\end{array}$ & $\begin{array}{l}2.42 \\
0.80-7.30 \\
0.12\end{array}$ & $\begin{array}{l}1.83 \\
0.78-4.29 \\
0.16\end{array}$ & - & $\begin{array}{l}1.74 \\
0.77-3.90 \\
0.18\end{array}$ & $\begin{array}{l}1.80 \\
0.78-4.11 \\
0.17\end{array}$ & $\begin{array}{l}1.79 \\
0.83-5.21 \\
0.12\end{array}$ & $\begin{array}{l}2.74 \\
0.98-7.68 \\
0.06\end{array}$ \\
\hline Female household head & $\begin{array}{l}0.71 \\
0.50-1.01 \\
0.06\end{array}$ & - & $\begin{array}{l}0.45 \\
0.26-0.80 \\
0.01\end{array}$ & $\begin{array}{l}0.59 \\
0.27-1.27 \\
0.18\end{array}$ & $\begin{array}{l}0.38 \\
0.24-0.60 \\
<0.001\end{array}$ & $\begin{array}{l}0.55 \\
0.29-1.05 \\
0.07\end{array}$ & $\begin{array}{l}0.65 \\
0.44-0.96 \\
0.03\end{array}$ & $\begin{array}{l}0.73 \\
0.41-1.31 \\
0.29\end{array}$ & $\begin{array}{l}0.40 \\
0.24-0.66 \\
<0.001\end{array}$ & $\begin{array}{l}0.73 \\
0.37-1.47 \\
0.38\end{array}$ \\
\hline \multicolumn{11}{|c|}{ Number of children living with you } \\
\hline None & ref & - & ref & - & ref & - & ref & ref & ref & ref \\
\hline 1 or 2 & $\begin{array}{l}1.09 \\
0.69-1.72 \\
0.72\end{array}$ & - & $\begin{array}{l}1.51 \\
0.71-3.22 \\
0.28\end{array}$ & - & $\begin{array}{l}1.16 \\
0.66-2.02 \\
0.61\end{array}$ & - & $\begin{array}{l}1.69 \\
1.00-2.84 \\
0.05\end{array}$ & $\begin{array}{l}1.55 \\
0.90-2.68 \\
0.11\end{array}$ & $\begin{array}{l}2.77 \\
1.31-5.85 \\
0.01\end{array}$ & $\begin{array}{l}2.25 \\
1.01-5.00 \\
0.05\end{array}$ \\
\hline 3 or more & $\begin{array}{l}1.20 \\
0.75-1.93 \\
0.46\end{array}$ & - & $\begin{array}{l}1.76 \\
0.81-3.81 \\
0.15\end{array}$ & - & $\begin{array}{l}1.33 \\
0.75-2.36 \\
0.33\end{array}$ & - & $\begin{array}{l}1.61 \\
0.93-2.98 \\
0.09\end{array}$ & $\begin{array}{l}1.36 \\
0.75-2.44 \\
0.31\end{array}$ & $\begin{array}{l}2.65 \\
1.23-5.73 \\
0.01\end{array}$ & $\begin{array}{l}2.36 \\
1.02-5.52 \\
0.05\end{array}$ \\
\hline $\begin{array}{l}\text { Personally earned in last } 12 \\
\text { months }\end{array}$ & $\begin{array}{l}1.66 \\
1.10-2.51 \\
0.02\end{array}$ & $\begin{array}{l}1.77 \\
1.14-2.73 \\
0.01\end{array}$ & $\begin{array}{l}1.29 \\
0.71-2.35 \\
0.41\end{array}$ & - & $\begin{array}{l}1.08 \\
0.68-1.72 \\
0.73\end{array}$ & - & $\begin{array}{l}1.00 \\
0.66-1.51 \\
0.99\end{array}$ & - & $\begin{array}{l}0.59 \\
0.37-0.95 \\
0.03\end{array}$ & $\begin{array}{l}0.65 \\
0.39-1.08 \\
0.09\end{array}$ \\
\hline \multicolumn{11}{|l|}{ Monthly household earning } \\
\hline$\$ 142$ or less & ref & - & ref & - & ref & - & ref & ref & ref & - \\
\hline$\$ 142-\$ 357$ & $\begin{array}{l}1.08 \\
0.69-1.71 \\
0.73\end{array}$ & - & $\begin{array}{l}1.18 \\
0.60-2.31 \\
0.64\end{array}$ & - & $\begin{array}{l}1.23 \\
0.72-2.10 \\
0.46\end{array}$ & - & $\begin{array}{l}1.42 \\
0.85-2.37 \\
0.17\end{array}$ & $\begin{array}{l}1.32 \\
0.78-2.24 \\
0.31\end{array}$ & $\begin{array}{l}1.15 \\
0.62-2.14 \\
0.65\end{array}$ & - \\
\hline$\$ 357-\$ 571$ & $\begin{array}{l}1.23 \\
0.69-2.19 \\
0.47\end{array}$ & - & $\begin{array}{l}0.85 \\
0.33-2.19 \\
0.74\end{array}$ & - & $\begin{array}{l}1.02 \\
0.50-2.08 \\
0.96\end{array}$ & - & $\begin{array}{l}1.14 \\
0.59-2.23 \\
0.70\end{array}$ & $\begin{array}{l}1.01 \\
0.50-2.04 \\
0.33\end{array}$ & $\begin{array}{l}1.16 \\
0.53-2.54 \\
0.71\end{array}$ & - \\
\hline Over $\$ 571$ & $\begin{array}{l}1.38 \\
0.69-2.43 \\
0.41\end{array}$ & - & $\begin{array}{l}1.18 \\
0.45-3.1 \\
0.74\end{array}$ & - & $\begin{array}{l}1.00 \\
0.45-2.20 \\
0.99\end{array}$ & - & $\begin{array}{l}2.15 \\
1.13-4.12 \\
0.02\end{array}$ & $\begin{array}{l}1.88 \\
0.93-3.81 \\
0.08\end{array}$ & $\begin{array}{l}2.1 \\
0.96-4.43 \\
0.06\end{array}$ & - \\
\hline
\end{tabular}

${ }^{a}$ Women experiencing violence before the last 12 months only have been removed from the denominators for physical and/or sexual violence $(n=89)$ and economic abuse $(n=46)$, past violence was not captured for emotional abuse

${ }^{\mathrm{b}}$ Widowed, divorced or separated grouped together in the economic abuse models

'Logical rule (Gelman and Hill 2007) applied for sexual debut missing values - this pertained mostly to older women who "don't remember" and we thus included them in the reference group in regression models. Notation: $a O R$ adjusted odds ratio (adjusted for all other covariates in the model), $95 \% C I$ confidence interval

\section{Younger Women, Partner Violence and Intervention Engagement}

Similar to other Sub-saharan African settings, younger age $<35$ years old is associated with physical and/or sexual IPV and emotional partner abuse in our cohort (Stöckl et al. 2014; Kapiga et al. 2017). This age group also differed in terms of programme uptake. As observed in the IMAGE trial setting, younger women attended less of the SfL training (Hargreaves et al. 2010). This suggests specific obstacles may affect younger women attendance across settings, for example, pressures looking after young children. The SfL training is a mandatory part of loan group meetings; hence, attendance could be affected by ability to make repayments. Further research to understand challenges that affect younger women's attendance and efforts to remove barriers are needed.

Intervention acceptability and group support was similar across ages; however, fewer younger women said being part of a microfinance group had a positive effect on their relationship. HIV risk factors, such as more sexual partners, transactional sex and partner controlling behaviours, were reported 
Table 7 Associations between IMAGE programme engagement and past-year partner violence and abuse

\begin{tabular}{|c|c|c|c|c|c|c|c|}
\hline & \multirow[b]{3}{*}{$\mathrm{n}(\%)$} & \multirow{2}{*}{\multicolumn{2}{|c|}{$\begin{array}{l}\text { Physical or sexual violence } \\
\text { Last } 12 \text { months }\end{array}$}} & \multirow{2}{*}{\multicolumn{2}{|c|}{$\frac{\text { Emotional abuse }}{\text { Last } 12 \text { months }}$}} & \multirow{2}{*}{\multicolumn{2}{|c|}{$\frac{\text { Economic abuse }}{\text { Last } 12 \text { months }}$}} \\
\hline & & & & & & & \\
\hline & & $\begin{array}{l}\mathrm{OR} \\
95 \% \mathrm{CI} \\
p \text { value }\end{array}$ & $\begin{array}{l}\mathrm{aOR} \\
95 \% \mathrm{CI} \\
p \text { value }\end{array}$ & $\begin{array}{l}\mathrm{OR} \\
95 \% \mathrm{CI} \\
p \text { value }\end{array}$ & $\begin{array}{l}\mathrm{aOR} \\
95 \% \mathrm{CI} \\
p \text { value }\end{array}$ & $\begin{array}{l}\text { OR } \\
95 \% \mathrm{CI} \\
p \text { value }\end{array}$ & $\begin{array}{l}\mathrm{aOR} \\
95 \% \mathrm{CI} \\
p \text { value }\end{array}$ \\
\hline \multicolumn{8}{|c|}{ Women's engagement with the IMAGE programme } \\
\hline Number in model & 860 & 771 & 765 & 860 & 854 & 814 & 808 \\
\hline \multicolumn{8}{|l|}{ Loan borrowing, in last 12 months } \\
\hline Continuously & $712(82.9)$ & ref & ref & ref & ref & ref & ref \\
\hline New loan & $112(13.0)$ & $\begin{array}{l}1.29 \\
0.61-2.72 \\
0.51\end{array}$ & $\begin{array}{l}0.88 \\
0.38-2.04 \\
0.78\end{array}$ & $\begin{array}{l}1.90 \\
1.10-3.31 \\
0.02\end{array}$ & $\begin{array}{l}1.78 \\
0.97-3.26 \\
0.06\end{array}$ & $\begin{array}{l}2.91 \\
1.68-5.01 \\
<0.001\end{array}$ & $\begin{array}{l}2.62 \\
1.44-4.77 \\
<0.001\end{array}$ \\
\hline Interrupted & $35(4.1)$ & $\begin{array}{l}2.54 \\
0.93-6.93 \\
0.07\end{array}$ & $\begin{array}{l}2.13 \\
0.71-6.38 \\
0.18\end{array}$ & $\begin{array}{l}2.76 \\
1.21-6.31 \\
0.02\end{array}$ & $\begin{array}{l}3.05 \\
1.26-7.38 \\
0.01\end{array}$ & $\begin{array}{l}0.73 \\
0.17-3.11 \\
0.67\end{array}$ & $\begin{array}{l}0.60 \\
0.14-2.63 \\
0.50\end{array}$ \\
\hline \multicolumn{8}{|l|}{ Training attendance } \\
\hline All & $455(52.9)$ & ref & ref & ref & ref & ref & ref \\
\hline Half or more & $282(32.8)$ & $\begin{array}{l}0.82 \\
0.43-1.56 \\
0.54\end{array}$ & $\begin{array}{l}0.53 \\
0.27-1.15 \\
0.07\end{array}$ & $\begin{array}{l}0.68 \\
0.41-1.11 \\
0.13\end{array}$ & $\begin{array}{l}0.52 \\
0.31-0.89 \\
0.02\end{array}$ & $\begin{array}{l}1.12 \\
0.66-1.89 \\
0.68\end{array}$ & $\begin{array}{l}0.97 \\
0.56-1.69 \\
0.92\end{array}$ \\
\hline Less than half & $123(14.3)$ & $\begin{array}{l}1.64 \\
0.81-3.30 \\
0.17\end{array}$ & $\begin{array}{l}1.07 \\
0.47-2.44 \\
0.87\end{array}$ & $\begin{array}{l}0.90 \\
0.48-1.67 \\
0.73\end{array}$ & $\begin{array}{l}0.58 \\
0.29-1.16 \\
0.12\end{array}$ & $\begin{array}{l}1.32 \\
0.68-2.57 \\
0.41\end{array}$ & $\begin{array}{l}0.76 \\
0.36-1.59 \\
0.46\end{array}$ \\
\hline \multicolumn{8}{|l|}{ Positive about the training and group } \\
\hline High (count:20) & $372(43.3)$ & ref & ref & ref & ref & ref & ref \\
\hline Medium (count: 17-19) & $244(40.0)$ & $\begin{array}{l}0.77 \\
0.41-1.43 \\
0.40\end{array}$ & $\begin{array}{l}0.70 \\
0.35-1.37 \\
0.30\end{array}$ & $\begin{array}{l}0.94 \\
0.59-1.52 \\
0.81\end{array}$ & $\begin{array}{l}0.99 \\
0.60-1.64 \\
0.97\end{array}$ & $\begin{array}{l}1.30 \\
0.77-2.17 \\
0.34\end{array}$ & $\begin{array}{l}1.09 \\
0.63-1.89 \\
0.77\end{array}$ \\
\hline Low (count: 5-16) & $144(16.7)$ & $\begin{array}{l}1.25 \\
0.62-2.51 \\
0.53\end{array}$ & $\begin{array}{l}0.93 \\
0.42-2.10 \\
0.85\end{array}$ & $\begin{array}{l}1.23 \\
0.69-2.20 \\
0.49\end{array}$ & $\begin{array}{l}1.25 \\
0.66-2.35 \\
0.97\end{array}$ & $\begin{array}{l}1.25 \\
0.64-2.44 \\
0.52\end{array}$ & $\begin{array}{l}0.93 \\
0.44-1.93 \\
0.84\end{array}$ \\
\hline \multicolumn{8}{|c|}{ Types of support provided by group members } \\
\hline None or some types ( $0-3$ types) & $141(16.4)$ & ref & ref & ref & ref & ref & ref \\
\hline Most types (4 types) & $271(31.5)$ & $\begin{array}{l}0.56 \\
0.28-1.11 \\
0.10\end{array}$ & $\begin{array}{l}0.50 \\
0.24-1.10 \\
0.07\end{array}$ & $\begin{array}{l}0.80 \\
0.43-1.48 \\
0.48\end{array}$ & $\begin{array}{l}0.90 \\
0.46-1.73 \\
0.75\end{array}$ & $\begin{array}{l}0.38 \\
0.20-0.71 \\
<0.001\end{array}$ & $\begin{array}{l}0.38 \\
0.19-0.74 \\
0.01\end{array}$ \\
\hline All types (5 types) & $448(52.1)$ & $\begin{array}{l}0.32 \\
0.16-0.63 \\
0.001\end{array}$ & $\begin{array}{l}0.27 \\
0.12-0.59 \\
<0.001\end{array}$ & $\begin{array}{l}0.75 \\
0.43-1.33 \\
0.33\end{array}$ & $\begin{array}{l}0.83 \\
0.44-1.56 \\
0.57\end{array}$ & $\begin{array}{l}0.39 \\
0.22-069 \\
<0.001\end{array}$ & $\begin{array}{l}0.41 \\
0.23-0.76 \\
0.01\end{array}$ \\
\hline
\end{tabular}

Adjusted odds ratio adjusted by women's age, household asset quintile and all other intervention factors in multivariable model, $95 \%$ CI $95 \%$ confidence interval

more by younger women in our cohort, as in national surveys. IMAGE is one of few microfinance plus interventions that has demonstrated reductions in HIV risk behaviours among younger women $<35$ (Pronyk et al. 2008; Cui et al. 2013). However, younger women are classed as a credit risk with more out-migration (Kim et al. 2007), as indicated by the higher drop-out rate during the IMAGE trial among this age group (Hargreaves et al. 2010). Therefore, standard microfinance practice remains as targeting women $>35$
(Pronyk et al. 2005a, b). Given the potential dual benefit of this intervention to reduce HIV and IPV risk, it might be time to re-evaluate operational risks versus the benefits of targeting women under 35 years in some contexts.

\section{Intervention Engagement and Partner Violence}

Women who had interrupted loan borrowing reported higher odds of IPV and emotional abuse. This could be related to IPV 
and abuse affecting women's ability to pay back loans, which has important implications for successful programme delivery, especially as this may indicate a greater issue affecting those who drop out. Further, the associations between starting a new loan and emotional and economic partner abuse may reflect pre-existing partner abuse or conversely indicate increased vulnerability to abuse among those newly joining the programme. This finding suggests a need to equip women from the outset with the skills to deal with potential financial conflict that may arise when first receiving new loans. This supports microfinance plus training interventions for IPV prevention, rather than microfinance alone, whist indicating that specific areas of financial conflict, or conflict arising from the woman's improved economic position, are still not addressed strongly enough even in such microfinance plus training programmes.

In terms of SfL training, attending all the training sessions, compared with attending half or more, was associated with increased odds of past-year emotional abuse. As seen in other violence prevention programs, it might be that women's own experience of violence motivates them to engage more with the intervention, potentially masking a positive effect of attending all training on IPV (Abramsky et al. 2014). This could suggest that in later sessions the topic of IPV can be addressed in even more depth, also discussing highly sensitive issues such as sexual IPV that is harder to address (Abramsky et al. 2014). Irregular attenders were likely absent from the loan group during survey sampling and therefore had very low intervention engagement; thus, the association with IPV could not be established. Notably, few women in relationships said that being part of a microfinance loan group made their relationship more difficult and there is an encouraging trend between training attendance and women reporting a positive influence on their relationship. However, it is important to bear in mind that women who perceived the training as having a positive effect on their relationship may be more likely to attend, as opposed to the other way round.

In our study, women who reported more support from group members also reported less past-year IPV and economic abuse. Loan groups with participatory gender training might provide the essential social support that improves self-esteem and emboldens women to challenge existing or new relationship power imbalances and have the confidence to leave abusive relationships (Brody et al. 2017). Hence, improving social capital, in conjunction with economic empowerment, is a potential mechanism that augments reductions in IPV. This finding could point towards the intervention reducing IPV through group support, although the reverse direction of effect is equally as likely. It is possible that women experiencing violence have less confidence to engage with the group and therefore receive lower levels of group support. However, this supports the original IMAGE trial's qualitative finding that reductions in IPV were brought about in a range of ways, including the provision of material and moral support to those experiencing abuse (Kim et al. 2007). We found that support was similar across household assets levels and age groups; however, women who had never been married reported less group support (Annex 2 in the ESM). Therefore, building group cohesion to support unmarried women is one area of potential intervention development, along with further research on promoting cohesion, such as how groups are formed, the importance of engaging in a group with peers and the frequency of meetings. In addition, further qualitative exploration to unpack the mechanisms by which group support might help protect against IPV in different types of relationships is needed.

\section{Strengths and Limitations}

The study strengths include a high response rate, inclusion of older women and extensive interviewer training emphasising research independence and confidentiality. Further, this is one of few studies of a scaled-up economic empowerment intervention. The study utilised loan group meetings to recruit women and therefore, women with irregular attendance due to factors, such as difficulties making loan repayment or issues at home including IPV, are likely to be under-represented in this sample. Violence in general is underreported, therefore likely underestimated in this study even though we used the WHO current gold standard questions (Abramsky et al. 2011). Further research is required to understand if those experiencing severe IPV have substantial challenges to engage in microfinance and microfinance plus programmes. Encouragingly, the MAISHA trial in Tanzania indicates that women participate in microfinance despite very high levels of violence including severe violence (Kapiga et al. 2017). Another key limitation is the cross-sectional design and therefore, no assertions of causality or direction of effects can be made. Results from the follow-up survey will allow further examination of the temporality of associations, as well as of the persistence of associations over time. There is also a need for additional analysis by severity and frequency of violence and abuse. Sensitivity analysis (results available on request) that modelled intervention engagement association with any type and all types of past-year violence yielded effects in the same direction as results presented. There is also no control group in this analysis, limiting our capacity to assess intervention impact. However, the 2006 randomised controlled trial has shown IMAGE to be an effective IPV prevention intervention. This study presents associations between IMAGE intervention engagement and IPV after delivery of phase 1 , whilst the influence of the phase 2 community mobilisation component will be explored at 1year follow-up. 


\section{Summary of Findings and Recommendations}

Our study found that the scaled-up IMAGE operational programme is widely acceptable among this population of women in rural South Africa. Women who attended more of the training were most likely to report that the intervention had a positive influence on their relationship. However, younger women $<35$ years were among the least likely to attend all the $>$ training and report relationship improvements. Younger women are at high risk of IPV and HIV and both purposely and self-excluded from these kinds of microfinance interventions. It may be time to rethink programme targeting and encourage participation among younger women. Our analysis shows that different types of IPV relate differently to intervention engagement, reinforcing the message that all types of IPV should be explicitly discussed in these kinds of interventions. Our results also indicate that women who experience IPV are more likely to attend all the gender training sessions. This suggests that there is opportunity to focus on sexual partner violence often persists even with promising interventions (Abramsky et al. 2014) and should therefore be addressed explicitly with topics built upon across all training sessions. The potential role of group support in augmenting reductions in partner violence highlights the importance of fostering group cohesion in this and other groupbased interventions. Our findings reinforce that microfinance combined with complementary training programs are crucial to reduce IPV, rather than microfinance alone programmesthat have limited evidence of positive effect on women's empowerment (de Mel et al. 2009; Niner 2019.).

\section{Conclusion}

These exploratory findings suggest that the IMAGE intervention is acceptable and continues to have a positive influence on women's intimate relationships, in a scaled-up operational setting. In addition, the study provided further insights how IMAGE and similar interventions might be further strengthened or targeted for specific groups.

Acknowledgements We would like to thank the IMAGE participants, as well as staff at IMAGE, Small Enterprise Foundation and Social Surveys Africa. Their substantial contribution of time and input made this study possible.

Data Availability and Reporting Guidelines The datasets generated and analysed during this current study are not publicly available for 10 years as they contain participant identification numbers. A deidentified dataset will be made available after this time in the London School of Hygiene and Tropical Medicine data repository. We have not included a CONSORT checklist as we are not reporting on a randomised controlled trial.
Author contributions MR and CW designed the overall study, obtained funding and provided critical comments to shape the direction of the manuscript and interpretation of results. LK conducted data analysis and drafted the manuscript. TA and HS provided input into the statistical methods, interpretation of the results and critical comments to shape the manuscript. TPN, LM, MM and SL reviewed the draft manuscripts and input in to the interpretation of the results. All authors input into the writing of the manuscript and approve its contents.

Funding Information Funds for the data collection and analysis were provided by an anonymous donor. Dr Ranganathan and Dr Stöckl were funded to participate in this analysis by the UK Economic and Social Research Council grant: ES/P003176/1 - GCRF: Economic empowerment and intimate partner violence in Sub-Saharan Africa. Dr. Ranganathan is a member of the STRIVE consortium, which produces research on the structural drivers of HIV, including stigma. The STRIVE consortium was funded by UKaid from the Department for International Development (http://strive.lshtm.ac.uk/). The views expressed do not necessarily reflect thedepartment's official policies.

\section{Compliance with Ethical Standards}

Conflict of Interest The authors declare that they have no conflict of interest.

Ethics Approval All procedures performed in studies involving human participants were in accordance with the ethical standards of the institutional and/or national research committee and with the 1964 Helsinki declaration and its later amendments or comparable ethical standards. Ethics approval was obtained from LSHTM (ref: 10724) and the University of Witwatersrand's Human Research Ethics Committee (HREC).

Informed Consent Informed consent was obtained from all individual participants included in the study. All women provided written informed consent prior to the survey interview.

Open Access This article is distributed under the terms of the Creative Commons Attribution 4.0 International License (http:// creativecommons.org/licenses/by/4.0/), which permits unrestricted use, distribution, and reproduction in any medium, provided you give appropriate credit to the original author(s) and the source, provide a link to the Creative Commons license, and indicate if changes were made.

\section{references}

Abramsky, T., Devries, K., Kiss, L., Nakuti, J., Kyegombe, N., Starmann, E., et al. (2014). Findings from the SASA! Study: A cluster randomized controlled trial to assess the impact of a community mobilization intervention to prevent violence against women and reduce HIV risk in Kampala, Uganda. BMC Medicine, 12, 122. https://doi.org/ 10.1186/s12916-014-0122-5.

Abramsky, T., Watts, C. H., Garcia-Moreno, C., Devries, K., Kiss, L., Ellsberg, M., et al. (2011). What factors are associated with recent intimate partner violence? Findings from the WHO multi-country study on women's health and domestic violence. BMC Public Health, 11, 109. https://doi.org/10.1186/1471-2458-11-109.

Brody, C., Hoop, T. d., Vojtkova, M., Warnock, R., Dunbar, M., Murthy, P., et al. (2017). Can self-help group programs improve women's empowerment? A systematic review. Journal of Development 
Effectiveness, 9(1), 15-40. https://doi.org/10.1080/19439342.2016. 1206607.

Cui, R. R., Lee, R., Thirumurthy, H., Muessig, K. E., \& Tucker, J. D. (2013). Microenterprise development interventions for sexual risk reduction: a systematic review. AIDS and Behavior, 17(9), 2864 2877. https://doi.org/10.1007/s10461-013-0582-1.

de Mel, S., McKenzie, D., \& Woodruff, C. (2009). Are women more credit constrained? Experimental evidence on gender and microenterprise returns. American Economic Journal: Applied Economics, 1(3), 1-32. https://doi.org/10.1257/app.1.3.1.

Durevall, D., \& Lindskog, A. (2015). Intimate partner violence and HIV in ten sub-Saharan African countries: What do the Demographic and Health Surveys tell us? The Lancet Global Health, 3(1), e34-e43. https://doi.org/10.1016/S2214-109X(14)70343-2.

Gibbs, A., Jacobson, J., \& Kerr Wilson, A. (2017). A global comprehensive review of economic interventions to prevent intimate partner violence and HIV risk behaviours. Global Health Action, 10 (sup2), 1290427. https://doi.org/10.1080/16549716.2017.1290427.

Gibbs, A., Willan, S., Misselhorn, A., \& Mangoma, J. (2012). Combined structural interventions for gender equality and livelihood security: a critical review of the evidence from southern and eastern Africa and the implications for young people. Journal of the International AIDS Society, 15(Suppl 1), 1-10. https://doi.org/10.7448/IAS.15.3.17362.

Hargreaves, J., Hatcher, A., Strange, V., Phetla, G., Busza, J., Kim, J., et al. (2010). Process evaluation of the Intervention with Microfinance for AIDS and Gender Equity (IMAGE) in rural South Africa. Health Education Research, 25(1), 27-40. https:// doi.org/10.1093/her/cyp054.

Gelman, A \& Hill J. (2007). Data Analysis Using Regression and Multilevel/Hierarchical Models. Cambridge University Press

Kapiga, S., Harvey, S., Muhammad, A. K., Stockl, H., Mshana, G., Hashim, R., et al. (2017). Prevalence of intimate partner violence and abuse and associated factors among women enrolled into a cluster randomised trial in northwestern Tanzania. BMC Public Health, 17(1), 190. https://doi.org/10.1186/s12889-017-4119-9.

Kennedy, C. E., Fonner, V. A., O’Reilly, K. R., \& Sweat, M. D. (2014). A systematic review of income generation interventions, including microfinance and vocational skills training, for HIV prevention. AIDS Care, 26(6), 659-673. https://doi.org/10.1080/09540121. 2013.845287.

Kim, J., Ferrari, G., Abramsky, T., Watts, C., Hargreaves, J., Morison, L., et al. (2009). Assessing the incremental effects of combining economic and health interventions: The IMAGE study in South Africa. Bulletin of the World Health Organization, 87(11), 824-832.

Kim, J. C., Watts, C. H., Hargreaves, J. R., Ndhlovu, L. X., Phetla, G., Morison, L. A., et al. (2007). Understanding the impact of a microfinance-based intervention on women's empowerment and the reduction of intimate partner violence in South Africa. American Journal of Public Health, 97(10), 1794-1802. https:// doi.org/10.2105/ajph.2006.095521.

Pronyk, M. F., Kim, J. C., Hargreaves, J. R., Makhubele, M. B., Morison, L. A., Watts, C., \& Porter, J. D. H. (2005a). Microfinance and HIV prevention - Emerging lessons from rural South Africa. Small Enterprise Development, 16(3), 26-38.
Miled, K. B. H., \& Rejeb, J.-E. B. (2015). Microfinance and poverty reduction: A review and synthesis of empirical evidence. Procedia - Social and Behavioral Sciences, 195, 705-712. https://doi.org/10. 1016/j.sbspro.2015.06.339.

Niner, S. (2019.). Why microfinance as aid isn't enough to empower women. https://theconversation.com/why-microfinance-as-aid-isntenough-to-empower-women-96632. Accessed 17/05/2019.

Pronyk, K., Hargreaves, M., Morison, W., et al. (2005b). Microfinance and HIV prevention - Emerging lessons from rural South Africa. Small Enterprise Development, 16(3), 26-38. https://doi.org/10. 3362/0957-1329.2005.030.

Pronyk, P. M., Hargreaves, J. R., Kim, J. C., Morison, L. A., Phetla, G., Watts, C., et al. (2006). Effect of a structural intervention for the prevention of intimate-partner violence and HIV in rural South Africa: A cluster randomised trial. The Lancet, 368(9551), 19731983. https://doi.org/10.1016/s0140-6736(06)69744-4.

Pronyk, P. M., Kim, J. C., Abramsky, T., Phetla, G., Hargreaves, J. R., Morison, L. A., et al. (2008). A combined microfinance and training intervention can reduce HIV risk behaviour in young female participants. Aids, 22(13), 1659-1665. https://doi.org/10.1097/QAD. 0b013e328307a040.

Ranganathan, M., Knight, L., Abramsky, T., Muvhango, L., Polzer Ngwato, T., Mbobelatsi, M., et al. (2019). Associations between women's economic and social empowerment and intimate partner violence: Findings from a microfinance plus program in rural North West Province, South Africa. Journal of Interpersonal Violence, 886260519836952. https://doi.org/10.1177/0886260519836952.

StataCorp (2015). Stata Statistical Software: Release 14.

Stöckl, H., March, L., Pallitto, C., Garcia-Moreno, C., \& on behalf of the, W. H. O. M.-c. S. t. (2014). Intimate partner violence among adolescents and young women: prevalence and associated factors in nine countries: a cross-sectional study. BMC Public Health, 14, 751. https://doi.org/10.1186/1471-2458-14-751.

UNAIDS (2016). Country Fact Sheet South Africa http://www.unaids. org/en/regionscountries/countries/southafrica/. Accessed 1st December 2017.

Vyas, S., \& Kumaranayake, L. (2006). Constructing socio-economic status indices: How to use principal components analysis. Health Policy and Planning, 21(6), 459-468. https://doi.org/10.1093/ heapol/czl029.

Vyas, S., \& Watts, C. (2009). How does economic empowerment affect women's risk of intimate partner violence in low and middle income countries? A systematic review of published evidence. Journal of International Development, 21(5), 577-602. https://doi.org/10. 1002/jid. 1500 .

Wagman, J. A., Gray, R. H., Campbell, J. C., Thoma, M., Ndyanabo, A., Ssekasanvu, J., et al. (2015). Effectiveness of an integrated intimate partner violence and HIV prevention intervention in Rakai, Uganda: analysis of an intervention in an existing cluster randomised cohort. The Lancet Global Health, 3(1), e23-e33. https://doi.org/10.1016/ s2214-109x(14)70344-4.

Publisher's Note Springer Nature remains neutral with regard to jurisdictional claims in published maps and institutional affiliations. 